\title{
THE ASSOCIATION DREPANOCLADO UNCINATI- HELIOSPERMETUM PUSILLI (ARABIDETALIA CAERULEAE, THLASPIETEA ROTUNDIFOLII) IN THE TRNOVSKI GOZD PLATEAU (SLOVENIA, NW DINARIC MTS)
}

\author{
Boštjan SURINA ${ }^{1} \&$ Branko VRE $\check{S}^{2}$
}

\begin{abstract}
The phytosociology and ecology of Heliosperma pusillum in freezing ravines of the Trnovski gozd plateau (Slovenia, NW Dinaric Mts) are discussed. The species thrive on shadowy, moist, cold and stable screes of boulders with long-lasting snow cover. The stands belonged to the association Drepanoclado uncinati-Heliospermetum pusilli (Salicion retusae, Arabidetalia caeruleae, Thlaspietea rotundifolii). Due to close proximity to the Julian Alps, the stands host a significant number of SE - Alpine and N-Illyrian species. Therefore, a new geographical variant Paederota lutea is described. Differential species for the geographical variant are Phyteuma scheuchzeri ssp. columnae, Valeriana saxatilis, Rhodothamnus chamaecistus, and Saxifraga cuneifolia. For less stable screes with smaller rocky particles a new subassociation salicetosum retusae is described, and the differential species for the subassociation are Salix retusa and Poa alpina. Stands of the association Drepanoclado-Heliospermetum var. geogr. Paederota lutea from the Trnovski gozd plateau are on the north-westernmost part of the distribution area of the Dinaric alliance Salicion retusae.

Key words: Dinaric Mts, Trnovski gozd, phytosociology, snow-bed vegetation, freezing ravine, Sanionia uncinata, Heliosperma pusillum, Drepanoclado uncinati-Heliospermetum pusilli, Salicion retusae, Thlaspietea rotundifolii

\section{Izvleček}

Preučili smo fitocenološke in okoljske razmere vrste Heliosperma pusillum v mraziščih v Trnovskem gozdu (Slovenija, SZ Dinaridi). Vrsta uspeva na senčnih, vlažnih in hladnih ustaljenih meliščih in skalnatih blokih z dolgotrajno snežno odejo. Sestoji, v katerih uspeva vrsta Heliosperma pusillum, pripadajo združbi Drepanoclado uncinati-Heliosperetum pusilli (Salicion retusae, Arabidetalia caeruleae, Thlaspietea rotundifolii). Zaradi bližine Julijskih Alp je v sestojih prisotnih precej jugovzhodno-alpskih in severno-ilirskih vrst. Zato smo opisali novo geografsko varianto in jo poimenovali po vrsti Paederota lutea var. geogr. nova. Razlikovalne vrste za geografsko varianto so Paederota lutea, Phyteuma scheuchzeri ssp. columnae, Rhodothamnus chamaecistus, Saxifraga cuneifolia, and Valeriana saxatilis. Na manj umirjenih meliščih z drobnejšim kamenjem smo opisali novo subasociacijo salicetosum retusae subass. nova. Za razlikovalnici smo določili vrsti Salix retusa in Poa alpina. Sestoji asociacije Drepanoclado-Heliospermetum var. geogr. Paederota lutea iz Trnovskega gozda so na skrajnem severozahodnem robu areala vegetacije snežnih dolinic iz dinarske zveze Salicion retusae.

Ključne besede: Dinaridi, Trnovski gozd, fitocenologija, vegetacija snežnih dolinic, mrazišče, Sanionia uncinata, Heliosperma pusillum, Drepanoclado uncinati-Heliospermetum pusilli, Salicion retusae, Thlaspietea rotundifolii
\end{abstract}

\section{INTRODUCTION}

Generally, the flora and vegetation of the Trnovski gozd plateau (W Slovenia, NW Dinaric Mts) are well known. Several botanists have focused their interest on this phytogeographically very inter- esting area, since the flora and vegetation consist of mixture of different geoelements: Alpine, Central-European, Illyrian (Illyricoid), Dinaric, and (Sub)Mediterranean. The great majority of the phytosociological studies were done on forest vegetation, and overviews were given lately

\footnotetext{
${ }^{1}$ Natural History Museum Rijeka, Lorenzov prolaz 1, HR-51000 Rijeka, Croatia, bostjan.surina@prirodoslovni.com

2 The Jovan Hadži Institute of Biology, Scientific and Research Centre of Slovenian Academy of Sciences and Arts, Novi $\operatorname{trg} 2$, SI-1000 Ljubljana, Slovenia, branevr@zrc-sazu.si
} 
by Surina (2001) and Dakskobler (2004). On the other hand, non-forest vegetation is still only poorly investigated. Poldini (1978), Kaligarič (1997), and Kaligarič \& Poldini (1997) studied calcareous dry grasslands and pastures on the southern part, while Dakskobler did research on calcareous open sedge swards and stony grasslands of the northern part of the plateau (Dakskobler 1999, 2006). Rock-crevice vegetation on the north-western part of the area (Forest reserve Govci, Zeleni rob) was studied by Dakskobler (1998), and on the southern and sunny slopes by Poldini (1978). The latter did the only research on scree vegetation of the study area. As a result, a new association Festuco carniolicae-Drypidetum jacquinianae was described. The same stands were mentioned again by Wraber during his floristical and chorological paper on Centaurea alpina (Wraber 2004a). A brief survey of phytosociological researches of non-forestal vegetation was recently made by Dakskobler (2006), while Wraber (2004b) did an overview of all botanical researches (and botanists) in the area.

Studies on the ecology and vegetation of freezing ravines in the Trnovski gozd started already in the 19th century. Krašan (1880) was the first who pointed out interesting vegetation patterns (namely, dwarf pine Pinus mugo at the bottom of the karst dolina) in Smrekova draga valley. Subsequently, Beck (1906) tried to explain this phenomenon on the case of the Paradana icehollow and Smrekova draga dolina (north-western part of the Trnovski gozd plateau), but the most detailed research on ecology and vegetation of freezing ravines was performed by Martinčič (1977). He studied the ecology and vegetation patterns of some dolinas in the Trnovski gozd plateau: Paradana ice-hollow, Smrekova draga, dolina in Poslušanje, dolina SW from Mt. Bukov vrh (north-western part of the plateau), and Ožgani grič valley (southern part of the plateau on the border between the sub-Mediterranean and Dinaric phytogeographical region). Actually, vegetation studies in Ožgani grič had already been done by Piskernik (1973), who recognised three "climo-coenoses": Hylocomio splendentisMoehringietum muscosae (the coldest growth sites with no woody species), Salico appendiculataeMoehringietum muscosae (shrub stands with Salix retusa), and Piceo excelsae-Moehringietum muscosae (forest stands with Picea abies). Martinčič (1977) classified freezing ravines in the Trnovski gozd as follows: freezing ravines with screes with natural spruce (Picea abies) stands (Ožgani grič, Poslušanje), with stands of dwarf-pine (Smrekova draga, dolina SW from Mt. Bukov vrh), and freezing ravines with permanent temperature inversion (Paradana ice-hollow).

There were also extensive phytosociological studies of spruce forests in the Dinaric Mts (Zupančič 1978, 1980, 1999) which were related to the research topic. On the Trnovski gozd plateau, Zupančič studied spruce stands in Smrekova draga (Lonicero caeruleae-Piceetum), Smrečje, Velika and Mala Lazna valleys (Stellario montanae-Piceetum). Spruce forests occur in the Dinaric Mts only azonally, since they are more or less restricted to freezing ravines or cold, moist, and shaded sites.

During our research on the ecology of Heliosperma pusillum in the Dinaric Mts (see Surina \& Vreš 2004), as well as flora and vegetation of the Trnovski gozd plateau, we observed very distinct and homogeneous stands with dominating Heliosperma pusillum and Sanionia uncinata (=Drepanocladus uncinatus) in freezing ravines on moist, cold and shadowy screes of boulders, most commonly, with long-lasting snow cover. Ecologically and/or floristically very similar stands were already observed and thoroughly studied on Mt. Snežnik (Piskernik 1973, Martinčič 1977, Surina \& Vreš 2004), as well as the Trnovski gozd plateau (Martinčič 1977). However, phytosociological observations from the Trnovski gozd plateau were still missing. Thus the aim of this study was to put forward an ecological assessment and to determine the syntaxonomical position of stands from the Trnovski gozd plateau.

\section{METHODS}

The phytosociology of stands with predominating Heliosperma pusillum was studied by applying the sigmatistic method (Braun-Blanquet 1964, Westhoff \& van der Maarel 1973, Dierschke 1994). Numerical analyses were carried out with the help of the computer programme SYNTAX (Podani 2001). The coverage index (I) was calculated according to Lausi et al. (1982). Nomenclature and taxonomy of the taxa are in agreement with the Mala flora Slovenije (Martinčič et al. 2007) and Annotated checklist of mosses of Europe and Macaronesia (Hill et al. 2006), while that of the syntaxa with Surina \& Vreš (2004), and geoelements and living forms with the Distribution atlas of the flora of Friuli Venezia Giulia (Poldini 
1991). All the syntaxonomic units in the paper and their authors are given in the Appendix.

Vegetation studies were done in two dolinas (Kraljeva kamra, a freezing ravine W from Kraljeva kamra), and an ice-hollow of Paradana (see Appendix). Similar stands were observed also in Smrekova draga, where they were only fragmentarily developed and covered only small scree patches up to $1 \mathrm{~m}^{2}$ within stands of dwarf pine (Pinus mugo) and/or large-leaved willow (Salix appendiculata). A distinct characteristic of those sites in Smrekova draga was - as already pointed out by Martinčič (1977) - cold and moist air constantly blowing from the hollows between the boulders of screes.

\section{RESULTS AND DISGUSSION}

In nine relevés we found only 32 species of flowering plants, and 17 species of cryptogams (Tables 1 \& 2). Hemicryptophytes (23 species, $\left.I_{c}=282\right)$, and cryptogams $\left(I_{c}=257\right)$ prevailed. Six species belong to phanerophytes, three to chamephytes (both $\mathrm{I}_{\mathrm{c}}=28$ ), while there were only 1 geophyte (Trisetum argenteum ${ }^{2}, \mathrm{I}_{\mathrm{c}}=5$ ), and therophyte (Galeopsis speciosa ${ }^{2}, \mathrm{I}_{\mathrm{c}}=2$ ). The median number of species per relevé area was 21.

The moss layer was well developed and covered 10-80 \% (average $35 \%$ ), while the herb layer covered $10-70 \%$ (average $43 \%$ ) of the relevé areas. The shrub layer was only poorly developed, hardly exceeded $50 \mathrm{~cm}$ in height, and was composed of only two willow species: Salix appendiculata $^{+1}$, and $S$. glabra ${ }^{+}$.

Frigophilous and hygrophilous mosses and flowering plants dominated. We found Heliosper-

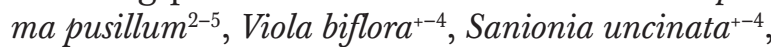
and Orthothecium rufescens ${ }^{+1}$ in all studied stands. Those species achieved also the highest coverage indices (Tab. 1). Other species with rather high frequency and coverage indices were Campylium stellatum $^{+-1}$, Paederota lute ${ }^{+-1}$, Salix retusa ${ }^{+-3}$, Tortella tortuosa $^{+-1}$, Pohlia elongata ssp. elongata ${ }^{+}$, Schistidium apocarpum ${ }^{+}$, and Distichium capillaceum ${ }^{+}$(Tab. 1).

The highest coverage indices were achieved by species which usually thrive on screes (Thlaspietea rotundifolii) - $\mathrm{I}_{\mathrm{c}}=120$ (six species), while most species (seven) were from the class Asplenietea trichomanis $\left(\mathrm{I}_{\mathrm{c}}=54\right)$. A rather high coverage index was achieved by species from the class Mulgedio-Aconitetea $\left(\mathrm{I}_{\mathrm{c}}=80\right.$; mainly due to domination of Viola biflora, and also Chrysosplenium alternifolium to a certain extent). The number of species and coverage indices of other syntaxa are presented in Table 2.

From the ecological and syntaxonomical point of view, the studied stands from the Trnovski gozd plateau resembled closely the stands of the association Drepanoclado uncinati-Heliospermetum pusilli from the Snežnik plateau. Characteristic species of the association, specially edifier species of Heliosperma pusillum and Sanionia uncinata, were fully represented and with more or less high coverage indices. Additionally, stands from the Trnovski gozd plateau thrived in very similar ecological conditions: wet, shady and cold screes in freezing ravines with long-lasting snow cover. An extensive syntaxonomical comparison showed that stands from the Trnovski gozd, Liburnian karst (sensu Beck 1901) and Velebit Mts clearly differ from other scree stands in the area of the SE Alps and NW Dinaric Mts (Surina 2005a, b, Surina \& Modrić 2006), and form a single, more or less uniform group within the alliance Salicion retusae (the synoptic table is available from the first author); thus classifying the stands from the Trnovski gozd plateau into the association Drepanoclado-Heliospermetum within the Dinaric alliance Salicion retusae, was indisputable. Stands from the Trnovski gozd plateau are at the north-westernmost extent of the distribution area of the alliance Salicion retusae.

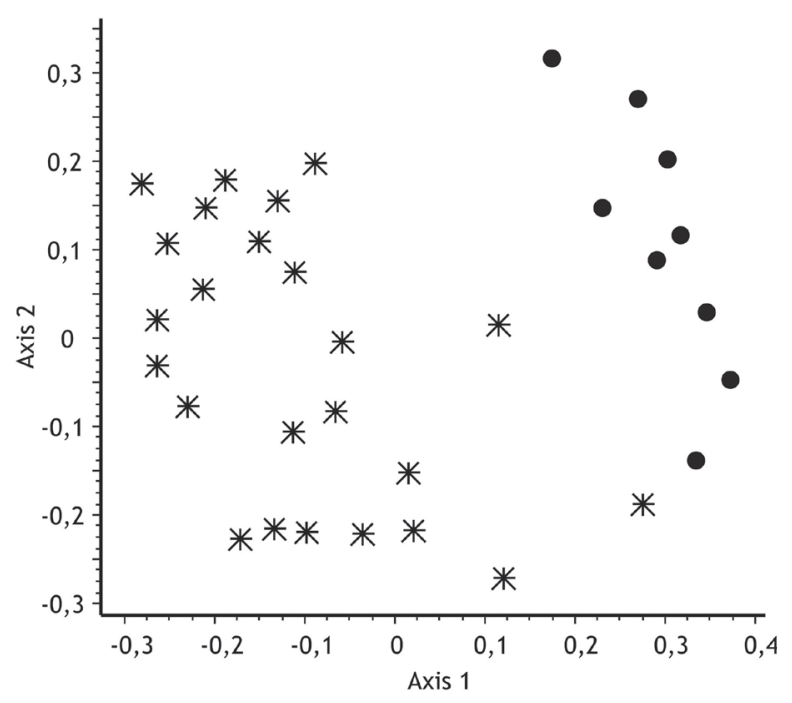

Figure 1: Two-dimensional scatter diagram of stands of the association Drepanoclado-Heliospermetum from the Trnovski gozd plateau (circles) and Mt Snežnik (stars) (NW Dinaric Mts); complete linkage, Sørensen's coefficient.

Slika 1: Dvoraszežnostni diagram sestojev asociacije Drepanoclado-Heliospermetum iz Trnovskega gozda (krogi) in Snežnika (zvezde); popolno povezovanje, Sørensenov koeficient. 
Table 1: Phytosociological table of the association Drepanoclado uncinati-Heliospermetum pusilli from the Trnovski gozd plateau.

Tabela 1: Fitocenološka tabela asociacije Drepanoclado uncinati-Heliospermetum pusilli iz Trnovskega gozda.

\begin{tabular}{|c|c|c|c|c|c|c|c|c|c|c|}
\hline Successive number & & 1 & 2 & $3 *$ & 4 & 5 & 6 & 7 & 8 & 9 \\
\hline Altitude (m) & & 1300 & 1353 & 1115 & 1115 & 1118 & 1115 & 1295 & 1295 & 1110 \\
\hline Aspect & & $\mathrm{W}$ & & $\mathrm{S}$ & $\mathrm{W}$ & $\mathrm{N}$ & SE & $\mathrm{E}$ & $\mathrm{NE}$ & $\mathrm{N}$ \\
\hline Inclination $\left({ }^{0}\right)$ & & 20 & & 45 & 45 & 45 & 45 & 20 & 25 & 30 \\
\hline Relevé area $\left(\mathrm{m}^{2}\right)$ & & 4 & 2 & 8 & 4 & 12 & 8 & 6 & 8 & 1 \\
\hline Stoniness $(\%)$ & & 20 & 10 & 20 & 10 & 20 & 15 & 50 & 10 & 40 \\
\hline Shrub layer (\%) & B & & & & 5 & 5 & & & & \\
\hline Herb layer (\%) & $\mathrm{C}$ & 20 & 10 & 70 & 60 & 60 & 70 & 30 & 30 & 40 \\
\hline Moss layer (\%) & $\mathrm{D}$ & 60 & 80 & 10 & 30 & 20 & 15 & 20 & 60 & 20 \\
\hline Number of flowering plants/relevé & & 27 & 12 & 24 & 22 & 18 & 21 & 21 & 12 & 12 \\
\hline
\end{tabular}

Characteristic species of the association

TR Heliosperma pusillum

$\begin{array}{cccccccccccc}\mathrm{C} & 2.3 & 2.3 & 4.3 & 4.3 & 3.3 & 4.3 & 3.3 & 3.3 & 5.3 & 100 & 78 \\ \mathrm{D} & 2.3 & 2.3 & 3.3 & 4.3 & 3.3 & 3.3 & 2.3 & +.3 & 2.3 & 100 & 62 \\ \mathrm{D} & +.3 & +.3 & +.3 & 1.3 & +.3 & . & +.3 & . & +.3 & 78 & 18 \\ \mathrm{C} & +.2 & + & + & + & . & . & . & . & . & 44 & 10 \\ \mathrm{D} & . & 1.3 & . & . & +.3 & . & . & . & . & 22 & 6\end{array}$

Sanionia uncinata

Campylium stellatum

Carex capillaris

Oncophorus virens

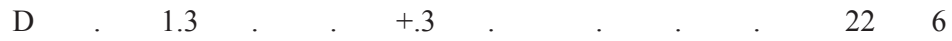

Phytogeographical differential species

AT Paederota lutea
AT Valeriana saxatilis
AT Phyteuma scheuchzeri ssp. columnae
VP Saxifraga cuneifolia
EP Rhodothamnus chamaecistus

$\begin{array}{lccccccccccc}\mathrm{C} & + & + & 1.2 & + & 1.2 & +.2 & . & . & . & 67 & 17 \\ \mathrm{C} & + & . & +.2 & . & . & . & + & . & . & 33 & 7 \\ \mathrm{C} & + & . & . & . & . & . & 1.2 & . & . & 22 & 6 \\ \mathrm{C} & . & . & . & . & . & . & . & . & 2.2 & 11 & 6 \\ \mathrm{C} & . & . & . & +.2 & . & . & . & . & . & 11 & 2\end{array}$

Differential species for the subassociation

TR Salix retusa

ES Poa alpina

\begin{tabular}{c|cccccc|}
\cline { 2 - 6 } $\mathrm{C}$ & +.2 & +.2 & 3.3 & 1.3 & 1.2 & +.2 \\
$\mathrm{C}$ &. &. & 3.2 & 1.1 & 1.2 & 2.2 \\
\cline { 2 - 7 }
\end{tabular}

TR Arabidetalia caeruleae (incl. Salicion retusae) \& Thlaspietea rotundifolii

Arabis alpina

Trisetum argenteum

Adenostyles glabra

Cystopteris montana

AT Asplenietea trichomanis

Cystopteris fragilis

Carex brachystachys

Cystopteris regia

Primula carniolica

ES Elyno-Seslerietea

Pinguicula alpina

Aster bellidiastrum

Tofieldia calyculata

AD Mulgedio-Aconitetea

Viola biflora

Chrysosplenium alternifolium

Salix appendiculata

Salix appendiculata

Salix glabra

\begin{tabular}{|c|c|c|c|c|c|c|c|c|c|c|c|}
\hline $\mathrm{C}$ & . & . & + & . & . & 1.2 & . & + & . & 33 & 9 \\
\hline $\mathrm{C}$ & . & . & . & . & . & . & + & + & . & 22 & 5 \\
\hline $\mathrm{C}$ & . & . & . & +.2 & . & . & . & . & . & 11 & 2 \\
\hline $\mathrm{C}$ & . & . & . & . & . & . & +.2 & . & . & 11 & 2 \\
\hline C & . & . & + & . & + & + & + & . & . & 44 & 10 \\
\hline $\mathrm{C}$ & . & . & . & +.2 & . & . & + & . & . & 22 & 5 \\
\hline $\mathrm{C}$ & +.2 & . & . & . & . & . & 1.2 & . & . & 22 & 6 \\
\hline C & . & . & . & +.2 & . & . & . & . & . & 11 & 2 \\
\hline & . & . & . & . & . & . & . & . & . & & \\
\hline $\mathrm{C}$ & + & . & . & . & . & . & + & . & . & 22 & 5 \\
\hline $\mathrm{C}$ & + & . & . & . & . & . & . & . & . & 11 & 2 \\
\hline $\mathrm{C}$ & + & . & . & . & . & . & . & . & . & 11 & 2 \\
\hline $\mathrm{C}$ & 1.1 & 1.1 & 4.2 & 3.2 & 2.2 & 2.2 & 3.2 & 2.2 & + & 100 & 55 \\
\hline $\mathrm{C}$ & . & . & . & . & . & +.2 & . & . & 1.2 & 22 & 6 \\
\hline B & . & . & . & + & . & . & . & . & . & 11 & 2 \\
\hline $\mathrm{C}$ & 1.2 & + & + & . & +.2 & . & . & . & . & 44 & 11 \\
\hline B & . & . & . & . & + & . & . & . & . & 11 & 2 \\
\hline $\mathrm{C}$ & . & . & . & . & + & . & . & . & . & 11 & 2 \\
\hline
\end{tabular}




\begin{tabular}{|c|c|c|c|c|c|c|c|c|c|c|c|c|c|}
\hline & Successive number & & 1 & 2 & $3 *$ & 4 & 5 & 6 & 7 & 8 & 9 & $\%$ & $I_{c}$ \\
\hline \multirow[t]{4}{*}{ FS } & Fagetalia sylvaticae & & & & & & & & & & & & \\
\hline & Saxifraga rotundifolia & $\mathrm{C}$ & . & . & . & . & . & 2.2 & . & +.2 & +.2 & 33 & 11 \\
\hline & Ranunculus platanifolius & $\mathrm{C}$ & . & . & +.2 & . & . & + & . & . & . & 22 & 5 \\
\hline & Festuca altissima & $\mathrm{C}$ & . & . & . & . & . & + & . & . & . & 11 & 2 \\
\hline \multirow[t]{3}{*}{ EP } & Erico-Pinetea & & & & & & & & & & & & \\
\hline & Rhododendron hirsutum & $\mathrm{C}$ & + & & + & + & & & & & & 33 & 7 \\
\hline & Vaccinium vitis-idaea & $\mathrm{C}$ & +.2 & & & & & & & & & 11 & 2 \\
\hline \multirow[t]{20}{*}{ VP } & Vaccinio-Piceetea & & & & & & & & & & & & \\
\hline & Lonicera caerulea & $\mathrm{C}$ & . & . & + & . & . & . & . & . & . & 11 & 2 \\
\hline & Other species & & & & & & & & & & & & \\
\hline & Parnassia palustris & $\mathrm{C}$ & + & . & . & . & . & & + & . & . & 22 & 5 \\
\hline & Galeopsis speciosa & $\mathrm{C}$ & . & . & . & . & . & . & . & + & . & 11 & 2 \\
\hline & Mosses and lichens & & & & & & & & & & & & \\
\hline & Orthothecium rufescens & $\mathrm{D}$ & 1.2 & +.2 & +.2 & 1.2 & +.2 & +.2 & 1.2 & 1.3 & 1.2 & 100 & 28 \\
\hline & Tortella tortuosa & $\mathrm{D}$ & 1.3 & +.3 & . & +.3 & +.3 & +.3 & 1.3 & +.3 & 1.3 & 89 & 23 \\
\hline & Pohlia elongata ssp. elongata & $\mathrm{D}$ & +.3 & . & +.3 & +.3 & +.3 & +.3 & +.3 & +.3 & . & 78 & 17 \\
\hline & Schistidium apocarpum & $\mathrm{D}$ & +.3 & +.3 & . & +.3 & +.3 & +.3 & . & +.3 & +.3 & 78 & 17 \\
\hline & Distichium capillaceum & $\mathrm{D}$ & . & +.3 & +.3 & . & +.3 & & +.3 & . & +.3 & 56 & 12 \\
\hline & Ctenidium molluscum & $\mathrm{D}$ & 1.3 & +.3 & . & . & . & & +.3 & +.3 & . & 44 & 11 \\
\hline & Hylocomium splendens & $\mathrm{D}$ & . & . & +.3 & . & . & 1.3 & . & . & 2.3 & 33 & 12 \\
\hline & Rhytidiadelphus loreus & $\mathrm{D}$ & . & 4.3 & +.3 & . & . & 1.3 & . & . & . & 33 & 15 \\
\hline & Rhytidiadelphus triquetrus & $\mathrm{D}$ & . & . & +.3 & +.3 & . & 1.3 & . & . & . & 33 & \\
\hline & Solorina saccata & $\mathrm{D}$ & + & . & . & . & 1.2 & . & . & + & . & 33 & \\
\hline & Dicranum scoparium & $\mathrm{D}$ & 1.3 & 1.3 & . & & . & . & . & . & . & 22 & \\
\hline & Polytrichastrum alpinum & $\mathrm{D}$ & . & . & +.3 & . & . & 1.3 & . & . & . & 22 & \\
\hline & Plagiochila asplenioides & $\mathrm{D}$ & +.2 & . & . & . & . & & . & . & . & 11 & 2 \\
\hline & Cladonia pyxidata & $\mathrm{D}$ & . & + & . & . & . & . & . & . & . & 11 & 2 \\
\hline
\end{tabular}

There were, however several notable differences between stands from the Trnovski gozd and Snežnik plateaus which were clearly supported also by the statistical analysis (Fig. 1). Stands from the Snežnik plateau hosted considerably a greater total number of species as well as number of species per relevé (Tab. 2). In both cases, coverage indices of species from the class Thlaspietea rotundifolii prevail, and there were also high indices of species of Mulgedio-Aconitetea in both cases, but a much lower number of species and covering indices of species of Elyno-Seslerietea, EricoPinetea, Vaccinio-Piceetea, and group of other species in the Trnovski gozd plateau. Due to the close proximity to the Julian Alps, a much higher number of species of Elyno-Seslerietea was expected. Furhermore, on the Trnovski gozd plateu we did not find any species from the class QuercoFagetea (but a higher coverage index of Fagetalia sylvaticae which is probably due to the lower altitude of the studied stands). Species from the order Seslerietalia juncifoliae were also missing, and here the reason was probably of phytogeographi- cal origin itself. The considerably lower number and coverage indices of species of mentioned syntaxa in stands of the Trnovski gozd plateau were most probably due to spatial isolation of studied stands. In most cases they were, incontrary to stands from the Snežnik plateau, isolated and not in direct contact with forest stands of spruces and beeches as well as stands of tall-herbs. Although the Mediterranean-montane geoelement prevailed in both studied areas, presences and coverage indices of European-Asiatic, EuropeanSibiric, and Arctic-Alpine geoelements were significantly smaller on the Trnovski gozd plateau. There were no paleotemperate and Alpine-Carpathian geoelements, while the coverage indices of Alpine and European geoelements were higher. From the phytogeographical point of view it was interesting to observe the higher coverage index of the SE Alpine-Illyrian geoelement and total absence of the Illyrian and SE-European geoelements on the Trnovski gozd plateau. Although all characteristic species of the syntaxon Drepanoclado-Heliospermetum occurred on the Trnovski 
gozd plateau, they had rather smaller constancy and coverage indices, however, still with sufficient presence. Interestingly, Polygonum viviparum, Vaccinium vitis-idaea, V. myrtillus, Homogyne sylvestris, Oxalis acetosella, Deschampsia caespitosa, Campanula cochleariifolia, Carex atrata, Festuca nitida etc., which were quite common in stands on the Snežnik plateau, were completely missing. On the other hand, some N-Illyrian and E-Alpine species occurred only in stands of the Trnovski gozd plateau: Paederota lutea ${ }^{+-1}$, Rhodotamnus chamaecistus $^{+}$, Valeriana saxatilis ${ }^{+}$, Saxifraga cuneifolia $^{2}$, and Phyteuma scheuchzeri ssp. columnae ${ }^{+-1}$. They are quite common in the studied area and only rarely occur further towards the SE Dinaric Mts (e.g., Saxifraga cuneifolia and Paederota lutea). More detailed information on the distribution area of the mentioned taxa and the phytogeographical peculiarities of the area in general are given in Dakskobler (1998), Dakskobler et al. (2000), and Surina (2002). The Code of phytosociological nomenclature (Weber et al. 2000) does not consider geographical variants, hence the correct typification of the syntaxa of this rank is not possible. Nevertheless, we chose above mentioned taxa as geographically differential for the association Drepanoclado-Heliospermetum var. geogr. Paederota lutea var. geogr. nova on the Trnovski gozd plateau. Other species of phytogeographical importance for the Trnovski gozd plateau were also Salix glabra and Primula carniolica, the latter as one of the most prominent endemic plants of Slovenian flora (see Dakskobler et al. 2004). Phytogeographical distinctions were also observed in other studied syntaxa from the Trnovski gozd plateau, e.g. Seslerio autumnalis-Fagetum var. geogr. Phyteuma columnae (Seslerio autumnalis-Fagetum var. geogr. Calamintha grandiflora on Snežnik plateau), Omphalodo-Fagetum var. geogr. Saxifraga cuneifolia (Omphalodo-Fagetum var. geogr. Calamintha grandiflora on Snežnik plateau, and $\mathrm{Ho}$ mogyno-Fagetum s. lat. in the Julian Alps), Primulo carniolicae-Caricetum firmae (Edraiantho graminifolii-Caricetum firmae on Snežnik plateau, Gentiano terglouensis-Caricetum firmae in the Julian Alps), Caricetum mucronatae var. geogr. Primula carniolica (Scabioso silenifoliae-Caricetum mucronatae on Snežnik plateau, Caricetum mucronatae s. lat. in the Julian Alps) etc. (see Dakskobler 1997, 2002, 2004, Surina 2002, Surina \& Wraber 2005, Surina \& Dakskobler 2005).

Within the stands from the Trnovski gozd plateau, two floristically and physiognomically distinct groups of relevés were observed (Tab. 1, Fig 2). In the first group (rel. 1-6), beside characteristic species of the association (Heliosperma pusillum and Sanionia uncinata above all), Salix retusa $^{+-3}$ and Poa alpina ${ }^{1-3}$ prevailed on screes with tinier stony particles of diameter $5-10$, and up to 20 $\mathrm{cm}$, whereas typical stands used to thrive on completely settled screes within and on larger blocks or even boulders. Therefore a new subassociation Drepanoclado-Heliospermetum salicetosum retusae, subass. nova was described, and for the differential species we chose Salix retusa and Poa alpina.

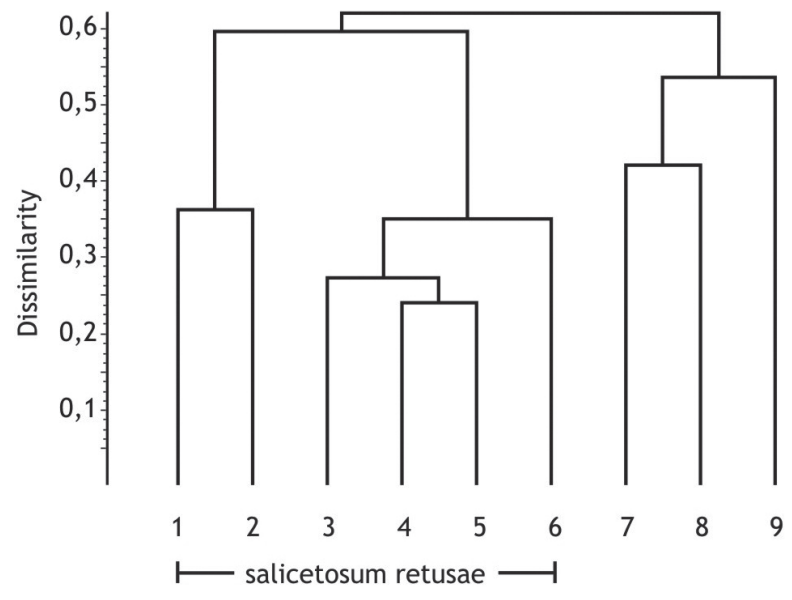

Figure 2: Dendrogram of relevés of the association Drepanoclado-Heliospermetum var. geogr. Paederota lutea var. geogr. nova on the Trnovski gozd plateau (complete linkage, similarity ratio).

Slika 2: Dendrogram popisov asociacije DrepanocladoHeliospermetum var. geogr. Paederota lutea var. geogr. nova iz Trnovskega gozda (popolno povezovanje, koeficient podobnosti).

Typification of the geographical variant Drepanoclado uncinati-Heliospermetum pusilli Surina \& Vreš 2004 var. geogr. Paederota lutea var. geogr. nova, and subassociation salicetosum retusae subass. nova: rel. No. 3 in the Table 1, holotypus hoc loco.

Classification of studied stands:

Thlaspietea rotundifolii $\mathrm{Br}$.-Bl. in Br.-Bl. \& Jenny 1926

Arabidetalia caeruleae Rübel ex Br.-Bl. 1949

Salicion retusae Horvat 1949

Drepanoclado uncinati-Heliospermetum pusilli Surina \& Vreš 2004

var. geogr. Paederota lutea var. geogr. nova

-salicetosum retusae subass. nova 
Table 2: Syntaxonomical and chorological groups, life forms and some phytosociological parameters in stands of the association Drepanoclado-Heliospermetum from the Trnovski gozd and Snežnik plateaus.

Tabela 2: Sintaksonomske in horološke skupine, življenjske oblike in nekateri fitocenološki parametri sestojev asociacije Drepanoclado-Heliospermetum iz Trnovskega gozda in Snežnika.

\begin{tabular}{|c|c|c|c|c|c|}
\hline & \multicolumn{2}{|c|}{$\begin{array}{l}\text { Trnov. gozd } \\
\text { plateau }\end{array}$} & \multicolumn{2}{|c|}{$\begin{array}{c}\text { Snežnik } \\
\text { plateau }\end{array}$} \\
\hline & & No. & Ic & No. & Ic \\
\hline \multirow{10}{*}{ 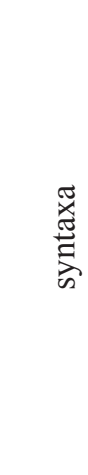 } & Thlaspietea rotundifolii $\mathrm{s}$. lat. & 6 & 120 & 9 & 124 \\
\hline & Asplenietea trichomanis & 7 & 54 & 5 & 37 \\
\hline & Seslerietalia juncifoliae & . & . & 4 & 6 \\
\hline & Elyno-Seslerietea & 4 & 36 & 20 & 66 \\
\hline & Mulgedio-Aconitetea & 4 & 80 & 11 & 88 \\
\hline & Fagetalia sylvaticae & 3 & 19 & 9 & 12 \\
\hline & Querco-Fagetea & . & . & 4 & 17 \\
\hline & Erico-Pinetea & 3 & 12 & 4 & 51 \\
\hline & Vaccinio-Piceetea & 2 & 9 & 20 & 92 \\
\hline & Other species & 3 & 17 & 8 & 96 \\
\hline \multirow{14}{*}{ 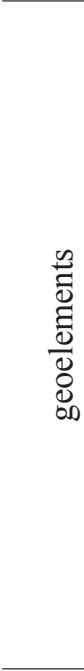 } & Cosmopolitan & 2 & 16 & 5 & 34 \\
\hline & Circumboreal & 4 & 89 & 18 & 163 \\
\hline & Paleotemperate & . & . & 2 & 2 \\
\hline & European-Asiatic & 3 & 6 & 7 & 28 \\
\hline & European-Siberian & 1 & 5 & 4 & 42 \\
\hline & Europaean & 3 & 30 & 4 & 4 \\
\hline & Arctic-Alpine & 5 & 28 & 13 & 89 \\
\hline & Alpine-Carpathian & . & . & 1 & 2 \\
\hline & Alpine & 2 & 14 & 1 & 12 \\
\hline & E-Alpine & 2 & 7 & . & . \\
\hline & Mediterranean-montane & 7 & 115 & 28 & 191 \\
\hline & SE-Europaean & . & . & 2 & 2 \\
\hline & Illyrian & . & . & 5 & 14 \\
\hline & N-Illyrian & 5 & 29 & 4 & 5 \\
\hline \multirow{6}{*}{ 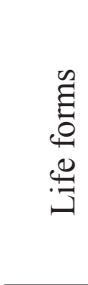 } & Phanerophytes & 6 & 28 & 11 & 64 \\
\hline & Chamephytes & 3 & 28 & 5 & 43 \\
\hline & Hemicryptophytes & 23 & 282 & 65 & 401 \\
\hline & Geophytes & 1 & 5 & 14 & 77 \\
\hline & Therophytes & 1 & 2 & . & . \\
\hline & Mosses and lichens & 17 & 257 & 19 & 325 \\
\hline \multicolumn{2}{|c|}{ altitude (min-max, Me) } & \multicolumn{2}{|c|}{$\begin{array}{c}1110-1300 \\
1118\end{array}$} & \multicolumn{2}{|c|}{$\begin{array}{c}1200-1525 \\
1273\end{array}$} \\
\hline \multicolumn{2}{|c|}{ total number of seed plants } & \multicolumn{2}{|c|}{32} & \multicolumn{2}{|c|}{96} \\
\hline \multicolumn{2}{|c|}{ species/relevé (min-max, Me), KV (\%) } & \multicolumn{2}{|c|}{$\begin{array}{c}12-27.21 \\
30\end{array}$} & \multicolumn{2}{|c|}{$\begin{array}{c}5-38,19 \\
41.7\end{array}$} \\
\hline
\end{tabular}




\section{CONGLUSIONS}

(a) We classified the studied stands from the Trnovski gozd plateau into the association Drepanoclado-Heliospermetum; (b) the stands are floristically impoverished and not optimally developed; nevertheless, our field diagnosis, analytical and extensive synoptic tables as well as numerical analyses still firmly supported their classification into the association Drepanoclado-Heliospermetum within the Dinaric alliance Salicion retusae; (c) due to phytogeographical peculiarities of the area and floristical distinction of the association from the Trnovski gozd plateau, a new geographical variant was described: Drepanoclado-Heliospermetum var. geogr. Paederota lutea, and for geographically differential taxa we chose Paederota lutea, Valeriana saxatilis, Saxifraga cuneifolia, Rhodotamnus chamaecistus, and Phyteuma scheuchzeri ssp. columnae. (d) Within the association stands were floristically and ecologically distinguished into the new subassociation Drepanoclado-Heliospermetum salicetosum retusae, subass. nova. It thrived on not completely settled screes with tinier stony particles. Differential species for the subassociation were Salix retusa and Poa alpina.

\section{APPENDIX}

\section{Phytosociological Table 1: localites of the re- levés}

NW Dinaric Mts, Slovenia, Trnovski gozd plateau

1, 7, 8 - Kraljeva kamra (MTB: 0049/141, UTM: VL19), moist and shady scree; $\mathbf{2}$ - freezing ravine $\mathrm{W}$ from Kraljeva kamra, NW from Mt Veliki Golak (MTB: 0049/141, UTM: VL19), moist scree with long-lasting snow cover; 3-6, 9 - Paradana (MTB: 0049/141, UTM: VL19), moist and shady screes. Leg. \& det.: B. Vreš and B. Surina, 18.7.2001.

\section{List of syntaxa mentioned in the article with authors}

Arabidetalia caeruleae Rübel ex Br.-Bl. 1949

Asplenietea trichomanis Br.-Bl. in Meier \& Br.-Bl. 1934

Caricetum mucronatae (Br.-Bl. in Br.-Bl. \& Jenny 1926) Thomaser 1977 var. geog. Primula carniolica Dakskobler 2006

Drepanoclado uncinati-Heliospermetum pusilli Surina \& Vreš 2004
Edraiantho graminifolii-Caricetum firmae (Horvat 1930) 1934

Elyno-Seslerietea Br.-Bl. 1948

Erico-Pinetea Horvat 1959

Fagetalia sylvaticae Pawl. in Pawl. et al. 1928

Festuco carniolicae-Drypidetum jacquinianae Poldini 1978

Gentiano terglouensis-Caricetum firmae T. Wraber 1970

Homogyno sylvestris-Fagetum Marinček et al. 1993

Lonicero caeruleae-Piceetum Zupančič (1980) 2000

Mulgedio-Aconitetea Hadač \& Klika in Klika 1948

Omphalodo-Fagetum (Tregubov 1957 corr. Puncer 1980) Marinček et al. 1993 var. geogr. Saxifraga cuneifolia Surina 2002

Omphalodo-Fagetum (Tregubov 1957 corr. Puncer 1980) Marinček et al. 1993 var. geogr. Calamintha grandiflora Surina 2002

Primulo carniolicae-Caricetum firmae Dakskobler 2006

Querco-Fagetea Br.-Bl. \& Vlieg. 1937

Salicion retusae Horvat 1949

Scabioso silenifoliae-Caricetum mucronatae Surina \& T. Wraber 2005

Seslerietalia juncifoliae Horvat 1930

Seslerioautumnalis-Fagetum (Horvat1950) M. Wraber ex Borhidi 1963 var. geogr. Phyteuma columnae Dakskobler 1997

Seslerio autumnalis-Fagetum (Horvat 1950) M. Wraber ex Borhidi 1963 var. geogr. Calamintha grandiflora Dakskobler 1997

Stellario montanae-Piceetum Zupančič 2000

Thlaspietea rotundifolii $\mathrm{Br}$.-Bl. in Br. Bl. \& Jenny 1926

Vaccinio-Piceetea Br.-Bl. 1939 emend. Zupančič (1976) 2000

\section{POVZETEK}

Asociacija Drepanoclado uncinati-Heliospermetum pusilli (Arabidetalia caeruleae, Thlaspietea rotundifolii) v Trnovskem gozdu (Slovenije, SZ Dinarsko gorstvo)

S pomočjo sigmatistične metode (Braun-Blanquet 1964, Westhoff \& van der Maarel 1973, Dierschke 1994) smo preučili fitocenološke in okoljske razmere četverozobega slanozora (Heliosperma pusillum) v mraziščih Trnovskega gozda. Slanozor uspeva na senčnih, vlažnih in bolj ali manj ustaljenih meliščih z dologotrajno snežno odejo. Preučevani sestoji pripadajo asociaciji Drepano- 
clado uncinati-Heliospermetum pusilli (Salicion retusae, Arabidetalia caeruleae, Thlaspietea rotundifolii), ki sta jo ista avtorja že prej opisala na Snežniku. Zaradi bližine Julijskih Alp je v teh sestojih prisotnih precej jugovzhodno-alpskih vrst, zato smo jih uvrstili v novo geografsko varianto - Paederota lutea. Ostale diferencialne vrste za geografsko varianto so: Phyteuma scheuchzeri ssp. columnae, Valeriana saxatilis, Rhodothamnus chamaecistus in Saxifraga cuneifolia. Na manj ustaljenih meliščih, kjer prevladuje vrsta Salix retusa, smo opisali novo subasociacijo: - salicetosum retusae, in za diferencialni vrsti izbrali Salix retusa in Poa alpina. Preučevani sestoji v Trnovskem gozdu predstavljajo skrajni severozahodni rob areala asociacije Drepanoclado-Heliospermetum in dinarske zveze Salicion retusae. Nomenklaturni tip za geografsko varianto Drepanoclado uncinati-Heliospermetum pusilli Surina \& Vreš 2004 var. geogr. Paederota lutea, var. geogr. nova, in subasociacijo -salicetosum retusae, subass. nova, holotypus hoc loco, je popis št. $3 \mathrm{v}$ tabeli 1 .

\section{REFERENCES}

Beck, G. 1901: Die Vegetationsverhältnisse der illyrischen Länder. Verlag von Wilhelm Engelmann, Leipzig, 534 pp.

Beck, G. 1906: Die Umkehrung der Pflanzenregionen in den Dolinen des Karstes. Sitzungber. d.Akad.d.Wiss.Wien, Mathem.-naturw. Kl. Bd. 115 (1-10): 3-19.

Braun-Blanquet, J. 1964: Pflanzensoziologie. Grundzüge der Vegetationskunde. 3. Auflage. Springer, Wien - New York, 865 pp.

Dakskobler, I. 1997: Geografske variante asociacije Seslerio autumnalis-Fagetum (Ht.) M. Wraber ex Borhidi 1963. Razprave IV. razreda SAZU 38 (8): 165-255.

Dakskobler, I. 1998: Vegetacija gozdnega rezervata Govci na severovzhodnem robu Trnovskega gozda (zahodna Slovenija). In: Diaci, J. (ed.): Zbornik referatov: XIX.gozdarski študijski dnevi. Logarska dolina, pp. 269-301.

Dakskobler, I. 1999: Contribution to the knowledge of the association Fraxino orni-Pinetum nigrae Martin-Bosse 1967. Wiss. Mitt. Niederösterr. Landesmuseum 12: 25-52.

Dakskobler, I. 2002: Jelovo-bukovi gozdovi na Bovškem (Julijske Alpe, severozahodna Slovenija). Razprave IV. razreda SAZU 43 (2): 109-155.
Dakskobler, I. 2004: Posebnosti rastja in rastlinstva Govcev na severnem robu Trnovskega gozda nad dolino Trebuše. Gozdarski vestnik 62 (5-6): 270-280.

Dakskobler, I. 2006: Calcareous open sedge swards and stony grasslands (Seslerietalia caeruleae) on the northern edge of the Trnovski gozd plateau (the Dinaric mountains, western Slovenia). Hacquetia 5 (1): 73-112.

Dakskobler, I., Jogan, N. \& Frajman, B. 2004: Primula carniolica Jacq. - kranjski jeglič. In: Čušin, B. (ed.): NATURA 2000 v Sloveniji. Rastline. Ljubljana, pp. 135-140.

Dakskobler, I., Urbančič, M. \& Wraber, A. 2000: Gozd bukve in jelke z dlakavim slečem $\mathrm{Om}$ phalodo-Fagetum (Tregubov 1957) Marinček et al. 1993 rhododendretosum hirsuti (Urbančič et al. 1979 nom. nud.) subass. nova v Trnovskem gozdu (zahodna Slovenija). Zbornik gozdarstva in lesarstva 62: 5-52

Dierschke, H. 1994: Pflanzensoziologie. Eugen Ulmer Verlag, Stuttgart, 683 pp.

Hill, M. O. \& Bell, N., Bruggeman-Nannenga, M. A., Brugués, M., Cano, M. J., Enroth, J., Flatberg, K. I., Frahm, J. P., Gallego, M.T., Garilleti, R., Guerra, J., Hedenäs, L., Holyoak, D. T., Hyvönen, Ignatov, M. S., Lara, F., Mazimpaka, V., Muńoz, J., Söderström, L. 2006: An annotated checklist of the mosses of Europe and Macaronesia. Journal of Bryology 28 (3): 198-267. (DOI: 10.1179/174328206X11 9998)

Kaligarič, M. 1997: Rastlinstvo Primorskega krasa in Slovenske Istre - travniki in pašniki. Zgodovinsko društvo za južno Primorsko: Znanstveno-raziskovalno središče Republike Slovenije, Koper, 111 pp.

Kaligarič, M. \& Poldini, L. 1997: Nuovi contributi per una tipologia fitosociologica delle praterie magre (Scorzoneretalia villosae $\mathrm{H}$-ić 1975) del Carso nordadriatico. Gortania 19: 119-148.

Krašan, F. 1880: Vergleichende Übersicht der Vegetationsverhältnisse der Grafschaften Görz und Gradisca. Österreichische Botanische Zeitschrift 30 (9): 281-286.

Lausi, D., Gerdol, R. \& Piccoli, F. 1982: Syntaxonomy of the Ostrya carpinifolia woods in the southern Alps (N-Italy) based on numerical methods. Studia Geobotanica 2: 41-58.

Martinčič, A. 1977: Prispevek k poznavanju ekologije mrazišč v Sloveniji. Botanično-ekološka skica. Razprave IV. razreda SAZU 20: 231-316. 
Martinčič, A., Wraber, T., Jogan, N., Podobnik, A., Turk, B., Vreš, B. Ravnik, V, Frajman, B., Strgulc Krajšek, S., Trčak, B., Bačič, T., Fischer, M. A., Eler, K. \& Surina, B. 2007: Mala flora Slovenije. Ključ za določanje praprotnic in semenk. Četrta dopolnjena in spremenjena izdaja. Tehniška založba Slovenije, Ljubljana, 967 pp.

Piskernik, M. 1973: Vegetacijske razmere v smrekovih mraziščih Slovenije. Zbornik gozdarstva in lesarstva 11 (1): 37-48.

Podani, J. 2001: SYN-TAX 2000. Computer programs for data analysis in ecology and systematics. Budapest, 53 pp.

Poldini, L. 1978: La vegetazione petrofila dei territori carsici nordadriatici. Poročila Vzhodnoalpsko-dinarskega društva za proučevanje vegetacije 14 (Spominski zbornik Maksa Wraberja): 297-324.

Poldini, L. 1991: Atlante corologico delle piante vascolari nel Friuli-Venezia Giulia. Regione autonoma Friuli-Venezia Giulia Direzione regionale delle foreste e dei parchi \& Universita degli studi di Trieste, Dipartimento di biologia, Udine, $899 \mathrm{pp}$.

Surina, B. 2001: Phytosociological researches of the fir-beech forest (Omphalodo-Fagetum s. lat.) at the western part of the Illyrian floral province. M.Sc Thesis. Biotechnical Faculty, Department of Biology, University of Ljubljana, Ljjubljana, 99 pp.

Surina, B. 2002: Phytogeographical differentiation in the Dinaric fir-beech forest (Omphalodo-Fagetum s. lat.) of the western part of the Illyrian floral province. Acta Botanica Croatica 61 (2): 145-178.

Surina, B. 2005a: Phytogeography and syntaxonomy of snow-bed vegetation on calcareous soils in the South-eastern Alps: a numerical approach. Annales, Series historia naturalis 15 (2): 223-238.

Surina, B. 2005b: Subalpinska in alpinska vegetacija Krnskega pogorja v Julijskih Alpah. Scopolia 57: 1-222.

Surina, B. \& Dakskobler, I. 2005: Delimitation of the alliances Caricion firmae (Seslerietalia albicantis) and Seslerion juncifoliae (Seslerietalia juncifoliae) in the southeastern Alps and Dinaric mountains. Plant Biosystems 139 (3): 399-410.

Surina, B. \& Modrić, Ž. 2006: Snow-bed vegetation (Arabidetalia caeruleae) in the Liburnian karst (NW Dinaric Mts). In: Arko-Pijevac, M.,
Kružić, B., Kovačić, M. (eds.): Natural history researches of the Rijeka region. 2nd Scientific Symposium with international participation. Rijeka, $14^{\text {th }}-17^{\text {th }}$ June 2006 . Abstracts. Rijeka, pp. 69-70.

Surina, B. \& Vreš, B. 2004: Phytsociological characteristics of sites of Heliosperma pusillum $(=\mathrm{Si}$ lene pusilla, Caryophyllaceae) in the freezing ravines on the Snežnik Plateau (SW Slovenia). Razprave IV. razreda SAZU 45 (2): 147-183.

Surina, B. \& Wraber, T. 2005: Phytosociology and ecology of Carex mucronata on the Mt. Snežnik (SW Slovenia, Liburnian Karst). Wulfenia 12: 97-112.

Weber, H. E., Moravec, J. \& Theurillat, J.-P. 2000: International Code of Phytosociological Nomenclature. 3rd edition. Journal of Vegetation Science 11 (5): 739-768.

Westhoff, V. \& van der Maarel, E. 1973: The Braun-Blanquet approach. In: Whittaker, R. H. (ed.): Ordination and Classification of Communities. Handbook of Vegetation Science 5. The Hague, pp. 619-726.

Wraber, T. 2004a: Kraška zgodba o alpskem glavincu. Proteus 67 (4): 148-155.

Wraber, T. 2004b: Rastlinstvo goriške okolice in njegovi raziskovalci. Goriški letnik 30-31: 171-192.

Zupančič, M. 1978: Die Vegetation der Frostmulde Smrečje (Trnovski gozd). Poročila Vzhodnoalpsko-dinarskega društva za proučevanje vegetacije 14 (Spominski zbornik Maksa Wraberja): 91-101.

Zupančič, M. 1980: Smrekovi gozdovi v mraziščih dinarskega gorstva Slovenije. Dela IV. razreda SAZU 24: 1-262.

Zupančič, M. 1999: Smrekovi gozdovi Slovenije (Spruce forests in Slovenia). Dela IV. razreda SAZU 36: 7-222. 